\title{
Experience of nurse entrepreneurs in long term institutions for elderly people
}

\author{
Experiência de enfermeiros empreendedores com instituições de longa permanência para idosos \\ Experiencia de enfermeros emprendedores con instituciones de larga permanencia para ancianos
}

'Serviço Nacional de Aprendizagem. Registro, São Paulo, Brazil. "Universidade Estadual Paulista "Júlio de Mesquita Filho". Botucatu, São Paulo, Brazil.

Fábio Moysés Trombeta'

ORCID: 0000-0002-2318-1567

Nádia Placidelli Ramos"

ORCID: 0000-0002-8204-0668

Silvia Cristina Mangini Bocchi"

ORCID: 0000-0002-2188-009X

How to cite this article:

Trombeta FM, Ramos NP, Bocchi SCM. Experience of nurse entrepreneurs in long term institutions for elderly people. Rev Bras Enferm. 2020;73(Suppl 3):e20190619. doi: http://dx.doi.org/10.1590/0034-7167-2019-0619

Corresponding author:

Silvia Cristina Mangini Bocchi

E-mail: silvia.bocchi@unesp.br

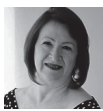

EDITOR IN CHIEF: Antonio José De Almeida Filho ASSOCIATE EDITOR: Priscilla Broca

Submission: 02-03-2020 Approval: 06-16-2020

\section{ABSTRACT}

Objective: To understand the nurse entrepreneur experience in long term institutions for elderly (LTIE) and to elaborate a theorical model regarding that experience process. Methods: Qualitative research with theorical saturation, through analysis of the 10th nondirective interview, audio-recorded and transcribed, according to the Grounded Theory, with nurses in activity and those who had to quit the business. Results: Three subprocesses emerged: (A) looking at the LTIE as a promising business to offer to the aging population; (B) discovering herself/himself without entrepreneur training/experience to carry on a social enterprise; (C) changing from preservation, expansion, and finally business discontinuance. The core category (process) was abstracted from the realignment of those subprocesses components: From the dream to expansion, preservation, and business abandonment: nurse training/experience for social enterprise as an intervening component. Final considerations: In light of the Business Model Canvas, it showed the experiential process little instrumented by the fundamentals of business management, to support the proposal, overview and altering business. Descriptors: Long Term Institutions for Elderly; Private Sector; Female and Male Nurses; Organization and Administration; Geriatric Nursing.

\section{RESUMO}

Objetivos: Compreender a experiência do enfermeiro empreendedor com instituição de longa permanência de idosos (ILPI) e elaborar modelo teórico desse processo de vivência. Métodos: Pesquisa qualitativa com saturação teórica, mediante a análise da $10^{\mathrm{a}}$ entrevista não diretiva, audiogravada e transcrita, segundo a Teoria Fundamentada nos Dados, com enfermeiros em atividades e desistentes do negócio. Resultados: Emergiram três subprocessos: (A) vislumbrando na ILPI negócio promissor com o envelhecimento populacional (B) descobrindo-se sem formação/experiência empresarial para o empreendimento social; (C) movendo-se entre a manutenção, a ampliação e a desistência do negócio. Do realinhamento dos componentes desses subprocessos, abstraiu-se a categoria central (processo): Do sonho à ampliação, manutenção e desistência do negócio ILPI: formação/experiência empresarial do enfermeiro para empreendimento social como componente interveniente. Considerações finais: À luz do Modelo de Negócios Canvas, mostrou-se processo experiencial pouco instrumentalizado pelos fundamentos da gestão empresarial, para apoiar na proposição, visualização e alteração de negócios.

Descritores: Instituições de Longa Permanência para Idosos; Setor Privado; Enfermeiras e Enfermeiros; Organização e Administração; Enfermagem Geriátrica.

\section{RESUMEN}

Objetivos: Comprender la experiencia del enfermero emprendedor con institución de larga permanencia de ancianos (ILPI) y elaborar modelo teórico de eso proceso de vivencia. Métodos: Investigación cualitativa con saturación teórica, mediante el análisis de la $10^{\mathrm{a}}$ entrevista no directiva, audiograbada y transcripta, segundo la Teoría Fundamentada en los Datos, con enfermeros en actividades y renunciantes del negocio. Resultados: Emergieron tres subprocesos: (A) vislumbrando en la ILPI negocio prometedor con el envejecimiento poblacional; (B) descubriéndose sin formación/experiencia empresarial para el emprendimiento social; (C) moviéndose entre la manutención, la ampliación y la desistencia del negocio. Del realineamiento de los componentes de esos subprocesos, se abstrajo la categoría central (proceso): Del sueño a la ampliación, manutención y desistencia del negocio ILPI: formación/ experiencia empresarial del enfermero para emprendimiento social como componente intermedio. Consideraciones finales: A la luz del Modelo de Negocios Canvas, se mostró proceso experiencial poco instrumentalizado por los fundamentos de la gestión empresarial, para apoyar en la proposición, visualización y alteración de negocios.

Descriptores: Instituciones de Larga Permanencia para Ancianos; Sector Privado; Enfermeras y Enfermeros; Organización y Administración; Enfermería Geriátrica. 


\section{INTRODUCTION}

This study is consistent with the positive impact of Brazilian aging population on the nursing profession, promoting opportunities for nursing autonomous professional exercise in front of the niche business working for individuals or companies, public or private institutions, which represent the institutions of long permanence for elderly (LPEs), in the reorganization of the support network for the binomial elderly-family.

In this network, LTIEs are considered to be governmental or nongovernmental establishments, of residential nature, destined to be a collective residence for people with 60 years old or more, with or without family support, in condition of freedom, dignity and citizenship ${ }^{(1)}$.

The existence of such establishments considers:

(a) the expected deficit of family caretakers in relation to the demographic profile and, along with the changes observed in family arrangements and the role of women in this context $t^{(2)}$;

(b) the increased frequency of elderly people with impairment in physical and/or cognitive independence for daily living activities (DLAs), which has happened in other countries; and the characteristics of the epidemiological transition that Brazil is going through, with the increased prevalence of morbidities related to chronic non-communicable diseases (CNCDs) ${ }^{(3)}$;

(c) the discrepancy between supply and demand for longterm care for the elderly, both in hospital units ${ }^{(4)}$ and in public or philanthropic LTIEs, added to the lack of support for families caring for their elderly relatives;

(d) the LTIE business as an opportunity, in the same way as in other countries ${ }^{(5,7)}$, Brazilian nurses have undertaken the business to provide services for the binomial family-elderly.

However, for an enterprise success, the professional must have competence and skills to identify the opportunity to transform it into a profitable organization. This will require creativity, innovation, courage, and ability to establish strategies that will outline their future.

Therefore, the question is: "How has the experience of the nurse entrepreneur with LTIEs been configured? The objectives of this study were outlined as a result of the lack of research on the subject and in response to that concern.

\section{OBJECTIVES}

Understand the experience of the nurse entrepreneur with LTIE and elaborate a theorical model of that experience process.

\section{METHODS}

\section{Ethical Aspects}

Research conducted after project approval by the Research Ethics Committee and signature of the Free and Informed Consent Term (FICT) by the participants/players. The privacy of their information was respected, and schedules and places were defined by them, safeguarding their right to anonymity.

\section{Theorical-methodological reference and type of study}

Qualitative research in the comprehensive approach were carried out according to the guide of Consolidated Criteria for
Reporting Qualitative Research (COREQ) ${ }^{(8)}$, using the methodological reference of the Grounded Theory $(\mathrm{GT})^{(9)}$ and the theorical reference of the Business Model Canvas ${ }^{(10)}$.

This model is a management tool and consists of nine basic components (customer segment, value proposal, channels, customer relationship, revenue sources, main resources, key activities, main partnerships, cost structure), gathered in four main business areas: customers, supply, infrastructure and financial viability ${ }^{(10)}$.

\section{Study scenario and players}

The study was carried out in three cities in the state interior of São Paulo, with nurse entrepreneurs in LTIEs, in two sample groups: active professionals and people who quit the business.

The nurses were located by phone numbers and addresses posted on the Internet with the purpose toe contact them and explained the survey, inviting them to the participate and scheduling the meeting. The "snowball"technique was used to locate nurses who had closed their business, through the interviewees in activity.

There was no withdrawal of the players who agreed to participate in the research, but difficulty to find agreeing nurses who had terminated their activities.

\section{Data source}

The unstructured individual interview was used as a data collection technique, with an average audio recording of 60 minutes, with as a starting point: "Could you tell me about your experience with your own LTIE business?

Data collection took place from July to November 2018 by one of the researchers trained in the technique of data collection, male and background in business administration.

\section{Data analysis}

At the end of the interviews, they were transcribed and submitted to analysis, with the support of the software NVivo 9 , by one of the researchers and validated by a second one, with training and experience in operating the stages of the GT methodological framework $^{(9)}$ : microanalysis, open coding, axial coding, selective coding.

As recommended for this type of research, the data collection and analysis stages took place concomitantly, until it was obtained the theorical saturation ${ }^{(9)}$ from the analysis of the tenth interview. For this, it was used one of the strategies suggested by the methodological reference for validation of the model discovered (Figure 1), recommending comparison of that with raw data, which has proven to be capable of explaining the experiences of LTIE nurse entrepreneurs.

\section{RESULTS}

\section{Characterization of players}

Ten LTIE nurse owners participated in the study, eight in activity and two who had recently closed their business, in three large cities in the state interior of São Paulo, aged 33 to 58 years, eight women and two men, all graduated in Nursing, with an average formation time of 12 years. 
These LTIEs are characterized as small businesses in the area of social entrepreneurship, with provision of services for elderly people, on average seven years of operation, investment of U\$S 12,000 [62.000 reais], eight employees, 16 residents and monthly turnover of U\$S 4,151 [22.000 reais].

\section{Theorical model extracted from the experience}

From the data analysis, according to the GT stages, it was understood the insight of the nurse enterpreneurs experience with LTIE.

The identifying categories and theorical relationships established enabled the development of an analytical and explanatory process of actions and interactions that make up the experience by three subprocesses: (A) foreseeing in LTIE a promising business with the aging population; (B) discovering himself/herself lacking business training/experience for social enterprise; (C) changing from preservation, expansion and business abandonment.

From the realignment of the components that formed the subprocesses, one can discover the central category that encompasses them, constituting then the experience process (Theorical Model), named: from dream to expansion, preservation and abandonment from the LTIE business: nurse training/experience for social enterprise as an intervening component (Figure 1).

Seeing in LTIE as a promising business with the aging population (A) is the first sub-process and stems from the nurse's perception as a successful opportunity to be an independent professional exercise, a social enterprise on the rise in the market, due to the increase in population life expectancy and reduced availability of support from family caretakers. This subprocess unfolds into three categories: perceiving the lack of support to the elderly from family caregivers as a social problem (A1); projecting himself/herself as a successful TLIE business entrepreneur (A2); deciding to own a $T L I E(A 3)$, as reported by $E 1$ :

[...] I see TLIE as a growing business in the market, because everyone tends to get older and today's family cannot afford long periods of time to care for or accompany their elderly during hospitalizations [...]. (E1)

Because it is a promising business in the market and the nurse judges himself/herself with affinity with the activity of providing services, through his/hers technical-scientific preparation to assist and manage nursing care, he/she decides to open or acquire a establishment and, in the context of his/hers experience as an owner of a LTIE, discovers himself/herself without business training/experience for a social enterprise (B) - second subprocess of the experience that unfolds in three categories (B1, B2 and B3).

Starting a business without a business plan (B1) is the decision of a nurse taking on a business in operation without a business diagnosis (B1.1), driven by a hasty attitude and based on an illusory interpretation of immediate profit as the owner of a LTIE, when supported by a superficial and non-technical judgment of business viability, either purchasing it or opening it, according to the account of E2:

[...] When I made the deal, I thought it would be easy to start with a house in operation, but once you get into the business you realize it is not easy at all. There is a lot of bureaucracy, both with the health surveillance and the fireman. Everything has to be within the law and that took time. It discouraged me. [...]. (E2)

Another risky attitude that emerged from the nurses' experiences in the LTIE venture is that they started the business without sufficient financial resources to set up and initially support the enterprise (B1.2), as reported by:

[...] My biggest challenge was financial, because when I started, I did not realize it would cost so much money [...]. (E1)

[...] I had any financial return yet to supply the nursing home, I am having to work in two hospitals [...]. (E2)

The third situation indicated by the nurse who did not plan the business opening occurred when he was surprised by the requirements for business regulations (B1.3). At that moment, he discovered the necessity to adapt the property, in addition to those changes he already predicted, and if there not were met immediately it would make the LTIE operation unfeasible due to the lack of a license issued by a supervisory body, resulting in the shutting down of the establishment, as tells us E7:

[...] The functioning of a retirement home is complicated because it has many supervisory bodies, nutrition inspector, health surveillance and fireman. I had to close the nursing home because the building of a ramp was not feasible [...]. (E7)

The second category which takes the nurse to the sub-process discovering herself/himself without businessperson training/ experience for social entrepreneurship (B) occurs when facing challenges as a LTIE (B2) owner. That category emerges from the chaining of seven subcategories, from B2.1 to B2.7.

It is in the exercise as a LTIE owner and, therefore, in the daily work process experienced, that the nurse classifies the business as not being easy (2.1), due to the numerous challenges faced and, many of them, inherent to the branch of activity "service rendering". As one of the characteristics of this type of business, the nurse owner ends up having a client with duality of attention (B2.2), the dependent family-elderly binomial, a unit which increases its complexity to meeting the demands. On one hand, the frail and dependent elderly in need of continuous care; and on the other, the relatives with peculiarities, as described by E2:

[...] The most difficult part happens when you give all your attention to a decompensated patient to refer and accompany him to emergency services and the family does not always recognize your work, complaining and criticizing [...]. (E2)

Moreover, in view of the peculiarity of this client, the owner nurse, who most of the time accumulates functions of technical responsible (TR), points out the work overload by associating the enterprise to a high demand for services requiring full-time dedication (B2.3), that is, an establishment operating 24 hours, with rare opportunities for breaks and vacations, according to E8:

[...] Sometimes I feel like going to my house, to the church, to take care of my obligations, but I never can, I stay here nonstop. 
It is hard to be absent, even in case of illness or taking a day off, it is rare [...]. (E8)

This workload is aggravated by the fact that, most of the time, LTIEs are small businesses with minimal staff, in which the nurse owner needs to work in several roles (B2.4) to fill the lack of staff professionals, as narrated by E3:

[...] As owner, I have to know everything that's happening and do whatever it takes. I end up offering supper to the elderly and putting them to bed, I manage the cleaning and when an employee is absent, for example the cook, I have to go to the kitchen. It is not easy to be an enterpreneur [...]. (E3)

Considering a challenge to maintain the ideal occupancy rate (B2.5) is another obstacle that arises from the experiences of LTIE nurse owners and, again, something inherent to the type of client attended. This is because most are in palliative care for finitude and therefore have high mortality rates. In addition, there is a permanent need to maintain the quality standard in humanized care, similar to home care, as they count:

[...] The challenge is to improve and maintain the quality of care for the elderly, so that they remain [...]. (E1)

[...] Another difficulty in maintaining the LTIE business is the instability in the number of elderly people, due to working with the finiteness of people [...]. (E4)

Added to the whole context of challenges absorbed by the nurse entrepreneur owning a $\mathrm{LTIE}$, when an altruism overcomes the purpose of the business (B2.6), he/she does slips in administrative management not committed to the business sustainability. That occurs because it is unclear how important it is to manage resources to ensure the survival of the enterprise, which, despite being social, needs profit, since it is not configured as a philanthropic entity.

This subcategory unfolds in two elements: presenting an inclination to altruistic work (B2.6.1); assuming a philanthropic posture in social enterprise (B2.6.2)

[...] Sometimes I buy medicine, [...] I have bought many diapers, among other things with money from my own pocket, to alleviate the problems of the elderly and to be calmer. These kinds of expenses end up weighing on me, but this is bad administration. (E2)

[...] / have two cases of unpaying elderly here. One woman is about to leave and the other woman I do not send away, because I have pity, because I know that the family will take her anywhere and will certainly die in less than a month [...]. (E8)

The last challenge, having difficulty with corporate administrative management (B2.7), listed by the LTIE nurse owner covers two elements: feeling unprepared to manage the business financially (B2.7.1); encountering difficulties in managing low-skilled human resources (B2.7.2).

[...] We nurses like to be at the forefront of care, but we have more difficulties with the administrative area to make payments, make the cashier to see how much is left, lost or missed in the month [...]. (E5)

[...] Human resources in this area, you have to train, because they are not prepared enough to care for the elderly, and most do not have enough qualities. Therefore, the turnover is high [...]. (E3)
(A1) Realizing the deficit of support of family caregivers for the elderly as a social problem;

(A2) Projecting successfully as an LTIE business entrepreneur:

(A3) Deciding to own a LTIE.

elderly (LTIE) as a promising business due

to the aging population (A)
Discovering oneself without business training/experience for social enterprise (B)

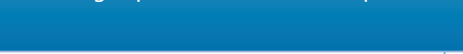

(B1) Starting up a business without a business plan: assuming a business in operation without a business diagnosis (B1.1); starting a business without sufficient financial amount for business installation and initial support (B1.2); being surprised with the requirements for business regularions (B1.3);

(B2) Facing challenges as an LTIE owner: it's not easy (B2.1); having a dual attention customer (B2.2); considering challenging to maintain the occupancy rate (B2.3); service requiring full dedication (B2.4); having to play several roles (B2.5); letting altruism overcome the purpose of the business (B2.6); having difficulty with business management (B2.7);

(B3) Trying to boost the business with cost reduction and quality maintenance: making investments with medium and long term return (B3.1); using their families' support in the business management (B3.2); outsourcing services (B3.3).
(C1) Expanding the enterprise: overcoming initial challenges by equating quality care with expenses based on the ideal number of clients (C1.1); motivating oneself to invest in business growth (C1.2);

(C2) Taking care of business maintenance;

(C3) Giving up being an entrepreneur: busines giving her/him physical and mental overload (C3.1); being frustrated with the business and as an entrepreneur (C3.2).

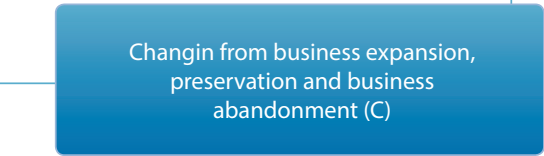

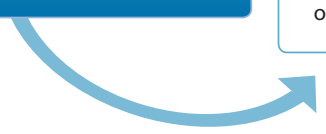

Figure 1 - Central category (Theorical model) - From dream to expansion, preservation, and business abandonment of the Long-Term Institution for the Elderly (LTIE): nurse training/experience for social enterprise as an intervening component, Brazil, 2019 
The sub-process, discovering himself/herself without business training/experience for social entrepreneurship (B) will unfold on the third category, when the nurse tries to leverage the business by reducing costs and quality maintenance (B3) in order to meet the challenges after starting the enterprise without a business plan (B1).

Trying to boost the business with cost reduction and quality maintenance (B3) involves attempts to make the business competitive in the market, through expansion of customer care services and advisory services to their families or hiring of outsourced accounting, legal, marketing and advertising services. This category brings together three sub-categories: making investments with medium and long-term returns (B3.1); using their families as a support in the business management (B3.2); outsourcing services (B3.3).

[...] / spent $\$ 1,887$ [R $\$ 10.000$ reais] to open an artesian well, but these days I get this amount back [...], I replaced some nursing assistants with caregivers. (E5)

[...] Here, I work as a family, with the help of my daughter and my husband. [...]. (E3)

[...] Anyway, I was able to hire a law firm to negotiate and draw up contracts with clients [...], physiotherapy, nutrition, medical and marketing services [...]. (E1)

The outcome of the experience of the nurse as a LTIE entrepreneur is configured in the sub-process changing from prevention, expansion and business abandonment (C), which unfolds in three categories: expanding the enterprise (C1); maintaining the business (C2); giving up being an entrepreneur (C3).

Expanding the business ( $\mathrm{C} 1$ ) is a condition aroused when the LTIE nurse owner realizes himself/herself overcoming the initial challenges when equating quality care with expenses based on the ideal number of customers (C1.1), as they report:

[...] In the beginning, it is difficult to invest [...]. The first year was the worst, but I have the LTIE for five years [...]. (E7)

[...] I have verified that, with 34 elderly, it will be possible to obtain a positive balance, with an adequate number of employees and qualified service [...]. (E5)

Having a feeling of success in the enterprise, by overcoming most of the problems and now a profitable establishment, the nurse is motivated to invest in business growth (C1.2), signaled by two elements: making it easier to hire, manage and train human resources (C1.2.1); aiming for a service presenting differentials (C1.2.2).

[...] I find it easy to hire qualified nursing staff, because I know them from hospitals and high school for nursing training, as well as in accompanying the staffI have trained. [...] My business is competitive in the market, because I can offer monthly fees compatible with the competition, but with additional services. (E1)

With time of experience and financially stabilized, this owner stops expanding, starting to watch over the business maintenance (C2), understanding that the number of residents is enough for offering a quality service with staff, and preserve themselves from financial, physical and psychic overloads, as reports E3:
[...] I have chosen to no longer work with the total of 16 available beds in the house. It was crazy, everything in a hurry. Of course, we earned more, but we worked a lot more, we were always worried and nowadays I have chosen to work with a small number of elderly people, because I can take care of them individually, without the need for many employees [...]. (E3)

Finally, some nurses end up abandoning entrepreneurship (C1.3), by understanding that LTIE is giving them physical and mental overload ( $\mathrm{C} 1.3 .1)$ and, consequently, becoming frustrated with the business and as entrepreneurs (C1.3.2) by discovering that they underestimated the complexity of the enterprise, even in an apparently promising market.

[...] It was very painful, but I chose to close down, even though I had financial losses, but the main reason for closing the nursing home was because I was too attached to the elderly. I wanted to offer the best to them, but there was a time when the families were distant from the problems and I had to solve everything and was still criticized [...]. (E9)

\section{DISCUSSION}

Analyzing the movement of the experience of nurses with LTIE, abstracted from the theorical model (Figure 1), it was found that the training/experience of the nurse in a social enterprise is an intervening component to accomplish the dream of keeping or expanding the business, differently from the ones who did not appropriate foundations and had to give up the business.

The theorical model pointed out that, although LTIE presents itself to the nurse as an area of activity and promising business in the field of service provision for the elderly-family binomial, it is still an experiential process little instrumented by the fundamentals of business management, when analyzed in light of the Business Model Canvas ${ }^{(10)}$.

This Model assumes nine basic components in business proposition, overview and transformation (customer segment, value proposal, channels, customer relationship, source of revenues, key resources, key activities, key partnerships, cost structure), gathered in four main areas of a business: customers, supply, infrastructure and financial viability ${ }^{(10)}$.

The nurse has started his/hers business precipitously, without any concern of seeking advice in business management in the field of LTIE social entrepreneurship and, therefore, has adventured in business without a preliminary study of feasibility, motivated to launch in a promising market and influenced by three symbols: LTIE as a possibility of autonomous job and immediate profit; nurse prepared technically and scientifically to assist and manage nursing care; inclination to altruistic work.

The misjudgment, supported by these symbols, is perceived later, amidst the countless challenges already faced with the establishment already in operation, by which the nurse owner discovers herself/himself without knowledge/experience for the management of a LTIE social enterprise, that is, in need for training of skills and abilities, far beyond assisting and managing nursing care.

The business plan is an essential instrument for the development and management of a new venture, including contributing 
to identify the viability of the business's idea in aspects such as financial, strategic, market/customer prospective planning, human resources required, among others things to avoid future risks ${ }^{(11)}$.

However, not carrying out a business plan is not a peculiarity of the nurse who own LTIEs, but a common practice among entrepreneurs in general. When consulted, it was found, in the state of São Paulo, that $61 \%$ did not seek advice from people or institutions to open the business, 55\% did not even prepare a business plan, as well as more than half did not carry out the planning of basic items before starting the company's activities ${ }^{(12)}$.

In the same study, it was found that a longer planning time allows better knowledge of the market before opening a business, which tends to increase the chances of success. The companies which dedicated more than six months in the business plan were the ones that prospered ${ }^{(11)}$.

It is inferred that the nurse in possession of the business plan to make the decision to acquire or start the LTIE enterprise will have greater chances to preserve himself/herself from physical, psychic and financial overloads, as well as to protect his/hers clients. This special care could change the reality portrayed in the abstract experience of this study, in ways that the nurse will acquire LTIEs aware of the business diagnosis, sufficient financial resources for installation and initial business support, as well as legal and regulatory requirements to settle business operations.

In addition, you should be aware that every endeavor has its negative points, such as the following pertinent challenges of maintaining the LTIE business: complexity of client elderly-family with duality of attention; maintenance of occupation rate, since most clients are in palliative care and, therefore, close to the end; the service requires a minimum sizing of staff for specialized attention in gerontology, which is still scarce in the country.

The workload is pointed out by most of the participants in this research, due to the accumulation of care management activities (technical responsible), with many of them assuming not only personnel and financial management, but also operational services.

The time availability, dedication and knowledge are considered essential for a good financial management. In most cases, the lack of resources to keep the enterprise's accounts up to date is due to the small business owner's lack of dedication to analyze which is the best solution to the financial problems $s^{(13)}$.

Financial management is understood as the set of administrative actions and procedures related to planning, execution, analysis and control of financial activities in small business, aiming at the maximum profit ${ }^{(13)}$. Good small business financial management does not combine private expenses to maintain the business and involves: (a) daily cash management, (b) investment management and (c) crisis management ${ }^{(14)}$.

Another challenging component in financial management pointed out by LTIE's nurse owners has been budgeting competitive costs in the market, taking into consideration: degree of dependence and complexity of care, occupation rate and non-paying elderly. It should be noted that, among the cost formulation components, nurses mentioned instability in maintaining the occupancy rate as one of the most difficult components to handle.

To minimize that difficulty, it should be necessary to conduct, in Brazil, a national and regional research on the hospitalization period of elderly people living in LTIEs, in order to substantiate cost calculations in those establishments. Although this type of study is also scarce in the international literature, one of them, carried out in the United States, showed that hospitalization period of elderly people in LTIEs was short, i.e., 53\% died within six months after admission ${ }^{(14)}$.

Another component raised by this research, peculiar to the profession and has been interfering in the financial management and sustainability of the business was the susceptibility of nurses to assume a philanthropic posture in the social enterprise, justified by an altruistic vocational trend and strengthened during graduation. This tendency contributes to the difficulty of conducting negotiations and managing contracts with estimated costs of services provided, especially when involves socially vulnerable clients.

Social companies, unlike non-profit organizations, use market mechanisms to seek solutions to social problems through their main activity, however they are considered companies, so they need to be economically competitive and profitable in order to survive ${ }^{(15)}$.

The study considers historical the link between feelings and values related to nursing, which were fundamental for its valorization, since the period when it was not configured as a profession, influencing it in the production of knowledge, in the organization of care, based on socializing structures of feelings such as: maternity, piety, altruism, empiricism, technicism, professionalism, scientism and humanism ${ }^{(16)}$.

Satisfactorily, recognizing the structuring and guiding values of nursing as a social practice contributes to the understanding of the recurrence of some nurse's attitudes and behaviors. Aiming at those values of ordering and care, as indicators of nursing as a social practice, may contribute to the recognition of what sustains or wears out the nurse's work in the process of observation and health care ${ }^{(17)}$.

Considering the LTIE's social entrepreneurship as an opportunity for the nurse to act independently, it is necessary to understand that, as a social entrepreneur, he/she will be at the forefront of a business model providing services. In the beginning, it will be for the client "elderly-families", but in an immediate future, it will be able to sell its services to the State and health insurance companies, especially from those caring for elderly dependent on long-term care and palliatives, from whom the hospitals and non-profit LTIEs will not be able to meet the demand.

This trend is already operationalized in other countries, as studies in the United States ${ }^{(5)}$, England ${ }^{(6)}$ and Denmark ${ }^{(7)}$ point out, with the State responding less and less to public LTIEs and becoming the majority purchaser and regulator of a private system services.

The third sub-process of the experience, changing from expansion, preservation and business abandonment, signals that nurses who stayed with the enterprise were those who, when discovered themselves without business training/experience for social enterprise, sought instrumentalized strategies for business management. They invested in cost reduction and quality maintenance, embraced solutions to make the company competitive in the market, through expansion of assistance services to customers, as well as purchasing directly from suppliers or wholesalers, outsourcing financial management, legal and marketing and 
advertising - some even made investments with medium and long term returns. However, most of them still need family support to help them alleviate the burden of some tasks related to business management, especially financial. Furthermore, a few have replaced nursing assistants with caregivers, i.e., someone without proper training, which is still common in Brazil.

Such a decision is risky, since the greater the training in nursing, the better the quality of care in LTIEs. Research conducted in Korea, where it is still acceptable to have certified nursing assistants as replacements for nurses, highlights that public policies in that country need to consider the need for a complete nursing team in LTIEs. This recommendation is based on results indicating that the hours of the nurse's stay at the LTIE was statistically significant for reducing the number of residents with psychotropic medication and cognitive impairment ${ }^{(18)}$.

In this respect, it should be noted that even in countries with advanced policies on the care of dependent elderly people, the training quality of professionals working in LTIEs has been a concern, including training actions. In the United Kingdom, Norway ${ }^{(19)}$ and Canada ${ }^{(20)}$, LTIEs are included as an option for immigrant labor, divulged in social networks - in the United Kingdom and Norway, mainly people from Eastern European countries ${ }^{(19)}$; and in Canada, Filipinos, mainly women and health workers ${ }^{(20)}$.

The frustrating outcome of the second group also stands out, with the business abandonment, highlighting to have underestimated the need for an entrepreneurial profile for the industry, as well as the complexity conferred by this market which seemed promising. It was a group of nurses who could not overcome the venture's initial challenges and did not seek resources in business management to boost a business.

The study points out the failure of companies associated with lack of capital or profit, leading the owner to psychological and financial overload. The closing of a company implies feelings of frustration, sadness, and sorrow of not having been able to have their own business, besides great financial repercussion. More than half of the entrepreneurs who have failed in their business lose all or part of the money invested, from their own resources or from relatives ${ }^{(12)}$.

A satisfying Brazilian market study corroborates this research, recommending nurse training with entrepreneurial skills and abilities, due to the relatively lower number of open nursing companies, when compared to other younger professions in the health area ${ }^{(21)}$.

\section{Study limitations}

One of the limitations of this research was the sample number to compose the group of the unsuccessful with LTIE social enterprises.

\section{Contributions to the Nursing}

The study contributed signaling the importance of building skills and abilities on social entrepreneurship, during nurse graduation, relying on business management foundations to understand that it is a business, therefore it needs to be not only beneficial to society, but also profitable.

Although nurses bring together opportunities to develop health products or services to meet the needs of clients/customers, historically they have been hesitant to establish business and compete in the health care market. Nowadays, they are moving towards those niche markets ${ }^{(11)}$.

Aiming at the expansion of professional opportunities, it is necessary that during the Nursing graduation course, besides the training focused on nursing care management, the student has to be introduced to business management as an expanding field of action.

\section{FINAL CONSIDERATIONS}

It was found that the experience of LTIE nurse entrepreneurs is still a working process little instrumented by fundamentals of business management.

Although LTIE' social entrepreneurship presents itself to nurses as a promising area of activity and business in the field of service provision for the elderly-family binomial, it still constitutes a risky business, because it matches with reasons for failure of most companies, from the first to the fifth year of activity, in the state of São Paulo.

\section{REFERENCES}

1. Agência Nacional de Vigilância Sanitária. Resolução RDC n. 283, de 26 de setembro de 2005 [Internet]. Brasília; 2005 [cited 2020 Jan 31]. Available from: http://portal.anvisa.gov.br/documents/10181/2718376/RDC_283_2005_COMP.pdf/a38f2055-c23a-4eca-94ed-76fa43acb1df

2. Giacomin KC, Duarte YAO, Camarano AA, Nunes DP, Fernandes D. Care and functional disabilities in daily activities - ELSI-Brazil. Rev Saude Publica. 2018;52(Suppl 2):9s. doi: 10.11606/s1518-8787.2018052000650

3. Nunes BP, Batista SRR, Andrade FB de, Souza-Junior PRB de, Lima-Costa MF, Facchini L A. Multimorbidity: the Brazilian longitudinal study of aging (ELSI-Brazil). Rev Saude Publica. 2018;52(Suppl 2):10s. doi: 10.11606/s1518-8787.2018052000637

4. Miranda GMD, Mendes ACG, Silva ALA. Population aging in Brazil: current and future social challenges and consequences. Rev Bras Geriatr Gerontol. 2016;19(3):507-19. doi: 10.1590/1809-98232016019.150140

5. Jacobs ML, Snow AL, Parmelee PA, Davis JA. Person-centered care practices in long-term care in the Deep South: consideration of structural, market, and administrator characteristics. J Appl Gerontol. 2018;37(3):349-70. doi: 10.1177/0733464816642583

6. Barron DN, West E. The quasi-market for adult residential care in the UK: do for-profit, not-for-profit or public sector residential care and nursing homes provide better quality care? Soc Sci Med. 2017;179:137-46. doi: 10.1016/j.socscimed.2017.02.037 
7. Hjelmar U, Bhatti Y, Petersen OH, Rostgaard T, Vrangbæk K. Public/private ownership and quality of care: evidence from Danish nursing homes. Soc Sci Med. 2018;216:41-9. doi: 10.1016/j.socscimed.2018.09.029

8. Tong A, Sainsbury P, Craig J. Consolidated criteria for reporting qualitative research (COREQ):a 32-item checklist for interviews and focus groups. Int J Qual Health Care. 2007;19(6):349-357. doi: 10.1093/intqhc/mzm042

9. Strauss A, Corbin J. Pesquisa qualitativa: técnicas e procedimentos para o desenvolvimento da pesquisa fundamentada. Porto Alegre: Artmed; 2008. 288 p.

10. Osterwalder A. Business model generation - inovação em modelos de negócios: um manual para visionários. Rio de Janeiro: Alta Books; 2011. $300 \mathrm{p}$.

11. Huber DL. Leadership and nursing care management. Elsevier: St. Louis; 2018.458 p.

12. Sebrae São Paulo. Entenda o motivo do sucesso e do fracasso das empresas [Internet]. São Paulo; 2017, [cited 2019 Jul 20]. Available from: http://bis.sebrae.com.br/bis/download.zhtml?t=D\&uid=333000e30d218194165cd787496e57f9

13. Sebrae Nacional. Como fazer a gestão financeira do pequeno negócio [Internet]. Brasília; 2018, [cited 2019 Jul 19]. Available from: http:// www.sebrae.com.br/sites/PortalSebrae/artigos/como-fazer-a-gestao-financeira-do-pequeno-negocio,d999a442d2e5a410VgnVCM1000003 b74010aRCRD

14. Kelly A, Conell-Price J, Covinsky K, Cenzer IS, Chang A, Boscardin W J et al. Length of stay for older adults residing in nursing homes at the end of life. J Am Geriatr Soc. 2010;58(9):1701-6. doi:10.1111/j.1532-5415.2010.03005.x

15. Information Resources Management Association - USA. Social entrepreneurship: concepts, methodologies, tools and applications. Hershey: IGI Global; 2019. 1077 p.

16. González JS, Ruiz MCS. Cultural history and aesthetics of nursing care. Rev Latino-Am Enfermagem. 2011;19(5):1096-105. doi: 10.1590/ S0104-11692011000500006

17. Zoboli ELCP, Schveitzer MC. Nursing values as social practice: a qualitative meta-synthesis Rev Latino-Am Enfermagem. 2013;21(3):695-703. doi: 10.1590/S0104-11692013000300007

18. Shin JH, Shin I-S. The effect of registered nurses on nursing home residents' outcomes, controlling for organizational and health care market factors. Geriatr Nurs. 2019;40(3):296-301. doi: 10.1016/j.gerinurse.2018.11.004

19. Christensen K, Hussein S, Ismail M. Migrants' decision-process shaping work destination choice: the case of long-term care work in the United Kingdom and Norway. Eur J Ageing. 2017;14(3):219-32. doi: 10.1007/s10433-016-0405-0

20. Novek S. Filipino health care aides and the nursing home labour market in Winnipeg. Can J Aging. 2013;32(4):405-16. doi: 10.1017/ S071498081300038X

21. Colichi RMB, Lima SAM. Entrepreneurship in Nursing compared to other health professions. Rev Eletr Enf [Internet]. 2018 [cited 2020 Jan 31];20:v20a11. Available from: 10.5216/ree.v20.49358 